\title{
ARTISANAL SHARK AND RAY FISHERIES IN SOUTH OF INDONESIA
}

\author{
Dharmadi ${ }^{1, *}$, Fahmi ${ }^{2}$ and Kurnaen Sumadhiharga ${ }^{2}$ \\ ${ }^{1}$ Research Centre for Captured Fisheries, Department of Marine Affairs and Fisheries \\ ${ }^{2}$ Research Centre for Oceanography, Indonesia Institute of Sciences \\ *e-mail:darma_ancol@yahoo.com
}

\begin{abstract}
Studies on artisanal fisheries of sharks and rays in Indonesia were carried out during 2001-2004. A market sampling method was employed to collect fisheries data from a number of major landings sites, namely: Pelabuhanratu and Cilacap in south coast of Java, Kedonganan in south coast of Bali and Tanjung Luar on the island of Lombok. Large proportions of the shark and ray landings were by-catch of tuna longlines and gillnets, and shark surface and bottom longlines from Tanjung Luar - east of Lombok. The shark landings were dominated by the families Carcharhinidae, Squalidae, Allopidae and Sphyrnidae, while rays were dominated by the Dasyatidae, Rhynchobatidae and Mobulidae. Most of the landings were processed to be dried and salted products for local consumptions. Some of them are exported to Asian countries. The most valuable part of sharks are their fins, which are a delicacy in Chinese cuisine. The major importers of Indonesian shark fins are Hongkong that contributed $46.3 \%$ of the total reported exports of shark fins from Indonesia.
\end{abstract}

Keywords: Shark and ray, Artisanal fisheries, South of Indonesia

\section{INTRODUCTION}

Current global landings of elasmobranch species reported by the Food and Agriculture Organization (FAO) of the United Nations exceed 600 thousands metric tons $(\mathrm{mt})$ per year while landings of sharks alone exceed 170 thousands mt (FAO report in Holts et al. (1998). Clarke et al. (2006) indicated that up to 73 million sharks are now being killed annually to supply the fin trade. This is three times higher than the official catch statistics reported by the FAO, because it included new data taken from illegal shark fin traders who unreported their catches. Whereas Blaber (2006) estimated that shark caught as by-catch forms about $16 \%$ of overall shark landings in Indonesia. In this country, a large quantity of sharks and rays are taken from shark surface, bottom longlines and as by-catch from tuna longlines, tuna gillnets, trammel nets and bottom trawls. Historically, the shark fishing effort in Indonesia began as by-catch from tuna longline fishing that developed in the 1970s. However, after 1988 when the price of shark fin rapidly increased, many fishermen focused on obtaining this commodity. According to Castro et al. (1999) by the late 1980s, shark fisheries were growing rapidly everywhere by the demand for shark fins and their high values. Although international markets for shark meat and other shark products are growing, there is uncertainty about the sustainability of these catches (Sylvana et al., 1998). Since most shark species have low fecundity, slow growth and longevity, they may be unable to recover easily from overexploitation (Berrow; Anon. in Sylvana et al., 1998). Sharks are oviparous or viviparous fishes with internal fertilization, and are long lived, late age at maturity and long gestation period, which means they can be very vulnerable to over fishing (Compagno, 1984; Last and Stevens, 1994; Castro et al., 1999).

The major problem on shark and ray fisheries in Indonesia is the lack of species and catch composition data. In the past, there was little economic incentive or impetus to study sharks. There is also a lack of fisheries catch data, as most fisheries simply do not report shark landings by species. They usually lump together all shark 
species and often all elasmobranches are included together. In the few cases, many fishermen caught many sharks until overload, the processed of shark at sea and just retain the fins. The majority of shark and ray landing in south of Indonesia (Palabuhanratu, Cilacap, Kedonganan and Tanjung Luar) are longlines and other fishing gears. Most of those fishes were processed to be dried and salted product for local consumptions.

This paper describes the characteristic of the landing sites investigated, the fishing gear used to capture sharks and rays, catch composition, production, season and the fishing ground, and description of local processing and marketing of shark and ray in the south of Indonesia.

\section{MATERIALS AND METHODS}

A total of 9 survey trips were undertaken from March 2001 to October 2004 at four landing sites in southern part of Indonesia i.e., Pelabuhanratu (West Java), Cilacap (Central Java), Kedonganan (Bali) and Tanjung Luar (West Nusa Tenggara). Species and size composition data of elasmobranches landed by local fishermen at a number of landing sites and/or markets in south of Indonesia were recorded from 2001 to 2004. This study was collaborations between RCCF (Research Center for Captured Fisheries), Indonesian Institute of Sciences (LIPI), Research Institute of Marine Fisheries (RIMF), Murdoch University, and CSIRO as part of the ACIAR funded project.

Species identification was carried out following the keys and descriptions in Compagno (1984), Last and Stevens (1994) and Gloerfelt-Tarp and Kailola (1984). Production, catch composition data and type of fishing gear were taken from the fishery office of Palabuhanratu, Cilacap-district Fisheries, Bali and West Nusa Tenggara Province Fisheries. Other data were collected through interviews with local fishermen.

\section{RESULTS}

\section{Characteristic of landing sites}

Palabuhanratu is an archipelago-fishing port which is the biggest fish-landing site in the southern part of West Java. This landing site is a base for drift-gillnet and the Danish seine (dogol/ cantrang) fisheries. Both of these fishing gears are used to catch pelagic fishes, and shark as by- catch, while shark-longlines are used to catch shark as a target fish. Other fishing gears operating from Palabuhanratu are hand lines, lift nets, bottom gill-nets, tuna longlines and purse seines. Most of the fishing vessels are operated mainly off West Java and South Sumatra. The vessels landing at this site are also from Cilacap (Central Java) and Muara Baru (Jakarta).

Cilacap has two landing sites; Pelabuhan Perikanan Cilacap (PPC) and Sentolo Kawat. PPC is the main fish-landing site in Cilacap, and most of large vessels are landed here. Whiles Sentolo Kawat is a smaller landing site, and only a few vessels landing at this site. Gillnets, trammel nets and longlines are the most common fishing gears which are applied to catch sharks and rays in Cilacap. However, most of the sharks were caught as by-catch in the gillnet and tuna longlines fisheries. There are also surface longlines to catch shark as a target fishery at Sentolo Kawat operated by fishermen from east of Java.

Kedonganan-Bali is a small landing site. This site is a fish landing for trammel net, gill net and bottom longlines vessels of $<10$ GT operating around Jimbaran Bay. Sharks are mainly caught by bottom longlines as by-catch, but dog fishes (squalids) are often caught in large numbers from this area. There is no auction system at this landing site, and all fishes at Kedonganan Bali are directly sold to fish traders.

Tanjung Luar is an artisanal fishing port. Surface and bottom longlines are the main fishing gears targeting sharks and rays operated from this landing site. Fishermen from Bugis-Sulawesi usually operate the surface longlines during the shark-catching season in this area (a period between June and November). Also, some surface longline boats from east Java usually come and stay at Tanjung Luar to catch and unload their catches. Whereas the bottom longlines are operated by fishermen from east of Lombok, and they stay in an island close to Tanjung Luar. All catches are auctioned and processed to be dried and smoked fish at this site.

\section{Fishing gears used to catch sharks and rays}

A large proportion of sharks and rays captured in south of Indonesia as a by-catch from tuna gillnet and longline fisheries, were landed at fishing ports throughout southern Indonesia such as Palabuhanratu (West Java), Cilacap (Central Java), 
Kedonganan (Bali), and Tanjung Luar (West Nusa Tenggara). Other fishing gears for catching shark and ray as by-catch are drift gillnets, longlines (surface and bottom longlines), fishnets and trammel nets. On the other hand, some fishing gears are targetted to catch sharks such as "shark surface longlines" and "shark bottom longlines". Both shark surface and bottom longlines were used by fishermen from Tanjung Luar. Descriptions of these fishing gears for shark capturing are as follows:

\section{a) Shark Surface longlines}

Shark surface longlines operated using a fishing vessel with specifications of $16 \mathrm{~m}$ length, $8 \mathrm{~m}$ width, 4-5 m depth and having a pair of 30 horse power (HP) machines. This fishing gear has a main line with $8 \mathrm{~mm}$ diameter syntetic rope, and $3.5 \mathrm{~m}$ branch lines with $4 \mathrm{~mm}$ diameter synthetic rope. Each branch has a hook at the end of the rope. The main line length is $3000 \mathrm{~m}$ and consists of 450 hooks with size of hook is 0.1 in $25 \mathrm{~cm}$ distances. It takes about 48 hours for getting the fishing area from the landing site. They begin to set of hooks at 15.00 to 18.00 p.m. and the hooks are hauled at 03.00 to 07.00 a.m., but it depends on the catch. The fishermen usually baits of pelagic fish and baby tuna (Thunnus sp.) to catch sharks. According to the fisher's information, baby tuna is a better bait than other fishes, due to the bleeding baby tuna can be an attractive prey for the school of sharks. In order to collect the baits, a gill net is usually set in the morning and it is hauled in the afternoon. The surface longlines operated by $4-5$ crews in Tanjung Luar spends 15 days at sea. There was no targeted species, but the sharks were mainly caught. Shark species such as thresher sharks (Alopias pelagicus), tiger sharks (Galeocerdo cuvier) and silky sharks (Carcharhinus falciformis) were often caught by this gear.

\section{b) Shark bottom longlines}

Shark bottom longlines is a fishing gear commonly operated at Tanjung Luar (east of Lombok). It is usualy operated by three crew members using a boat of $12 \mathrm{~m}$ long and $1.5 \mathrm{~m}$ wide, and a pair of $25 \mathrm{HP}$ of engine. This gear consists of main line, branch line and hooks. The length of main line is $300 \mathrm{~m}$ with diameter of the line is $8 \mathrm{~mm}$. The branch line length is $90 \mathrm{~m}$ with 4 $\mathrm{mm}$ in diameter. Each branch line is embedded 25 hooks (no. 1). The fishing duration is around 15 days, where six to seven days are used to look for baits, and another seven days for the fishing activities. The distance from the landing site to the fishing area is about one to three day trip. At the fishing area, they set the hooks with baits attached at $15.00 \mathrm{pm}$ and finish it by $17.00 \mathrm{p} . \mathrm{m}$., then at 03.00 a.m. to 08.00 p.m. the lines are hauled, but the duration of the process depends on the number of baits they used. This fishermen usually use baby tuna and snapper as baits. There are no target species of shark, but it mainly catches deepwater sharks (squalids). However, tiger shark (Galeocerdo cuvier), hammerhead sharks (Sphyrna spp.), silky sharks (Carcharhinus falciformis) and some big rays are often caught.

\section{Main species of sharks and rays caught}

The main species that were usually caught based on the fishing gear types from several fish landing sites is shown in Table 1. It seems that Carcharhinus falciformis was the most common shark species landing at Palabuhanratu, Cilacap and Tanjung Luar landing sites, where it was caught by drift gillnet and shark surface longlines, while genus Centrophorus was often caught by bottom longlines.

\section{Sharks and rays caught based on fishing gear types}

Figure 1 shows the historical catch of sharks that were caught by tuna longlines and gillnets at Palabuhanratu from 1993 to 2001. The total catch of sharks by tuna longlines landing at this location tended to decrease, due to the decline in the numbers of fishing gear, but the total catch of sharks by gillnet were relatively stable.

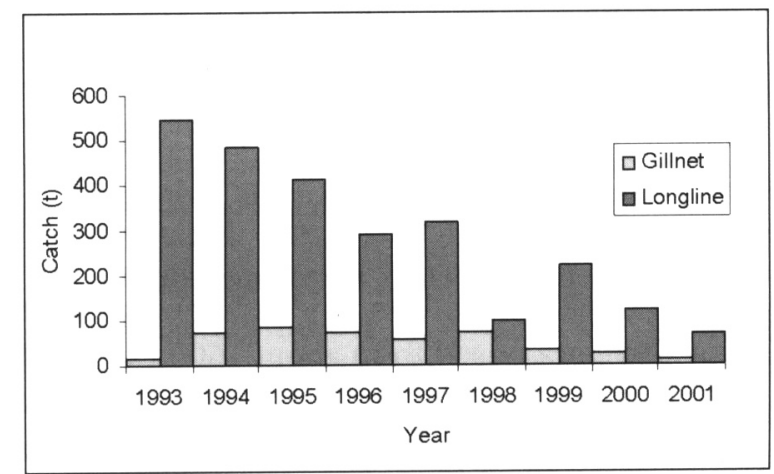

Figure 1. Catch patterns of shark based on fishing gear type at Palabuhanratu landing site (Sources: Pelabuhanratu Fishing Port, 2002). 
Table 1. Main species of sharks and rays landed at Palabuhanratu, Cilacap, Kedonganan and Tanjung Luar.

\begin{tabular}{|l|l|l|l|l|}
\hline Fishing gear types & Palabuhanratu & Cilacap & Kedonganan & Tanjung Luar \\
\hline Drift gillnet & Mobula japonica & M. japonica & $\begin{array}{l}\text { Carcharhinus } \\
\text { brevipinna }\end{array}$ & M. japonica \\
\hline & C. falciformis & M. tarapicana & & C. falciformis \\
\hline & & C. falciformis & & C. sorrah \\
\hline Shark surface longline & Prionace glauca & C. falciformis & Alopias pelagicus & C. falciformis \\
\hline & C. falciformis & C. sorrah & C. obscurus & C. amblyrhynchos \\
\hline & & C. brevipinna & & S. lewini \\
\hline & & & & P. glauca \\
\hline Shark bottom longline & $\begin{array}{l}\text { Centrophorus } \\
\text { niaukang }\end{array}$ & Squalus megalops & Squalus sp. 3b & Hexanchus griseus \\
\hline & & $\begin{array}{l}\text { Centrophorus } \\
\text { niaukang }\end{array}$ & Mustelus sp.1 & Centrophorus sp.1 \\
\hline Trammel net & & Himantura sp.1 & Rhinobatos sp.1 & -.-... . \\
\hline & - & H. gerrardi & Rhinobatos sp.2 & \\
\hline
\end{tabular}

The total catch of sharks and rays by tuna longlines landing at Cilacap (Fig. 2) fluctuated, but it decreased during the last seven years (1997 2003). Whiles there was a gradual decrease in the total catch of sharks and rays (Fig. 3) by tuna longlines and tuna gillnets landing in Bali from 1999 to 2003.

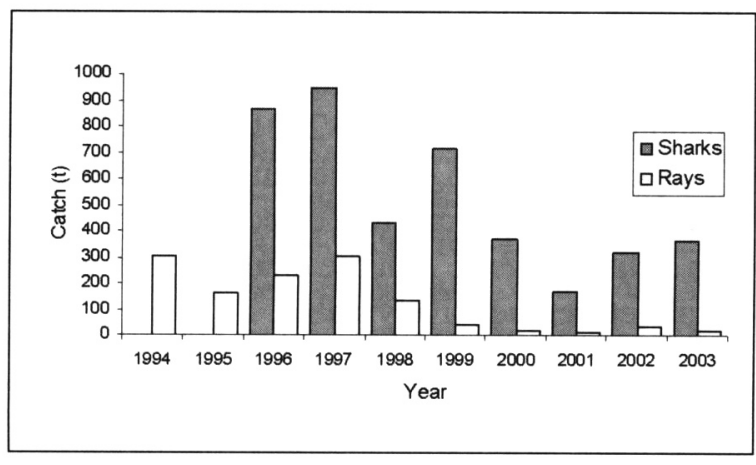

Figure 2. Catch of shark and ray based on fishing gear landing at Cilacap landing site (Sources: Cilacap Fishing Port, 2004).

The total catch of longline fisheries in West Nusa Tenggara raised from about $1600 \mathrm{t}$ in 1998 to about 2300 t in 1999 , due to increasing numbers of fishing vessels. Then from 1999 to 2001, the total catch of sharks was relatively constant (Fig. 4a). However, after 2001 the total catch of longlines fisheries decreased significantly due to a decline

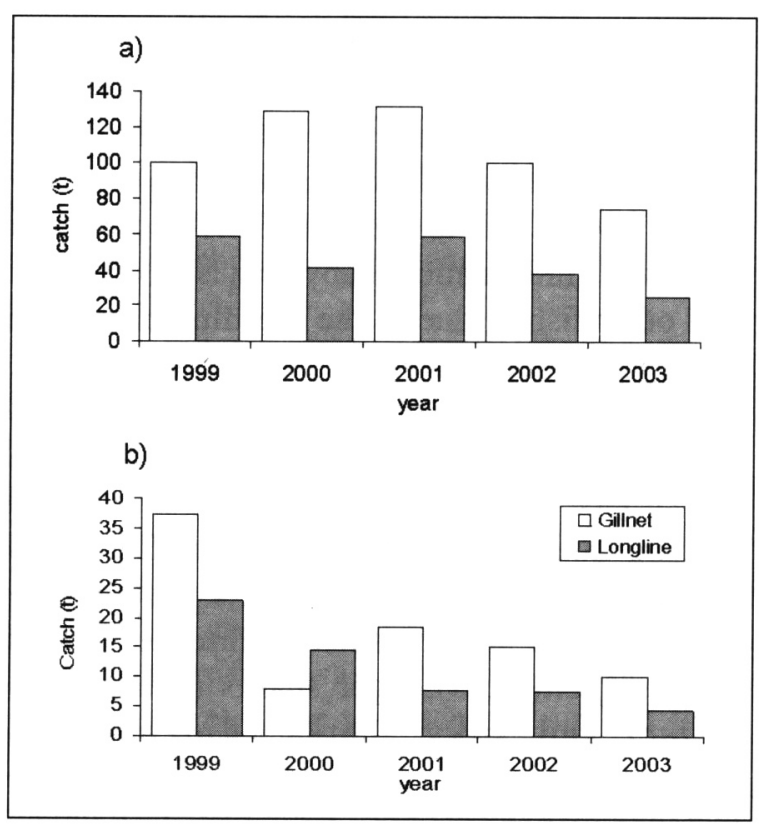

Figure 3. Catch pattern of sharks (a) and rays (b) based on fishing gear type at Kedonganan landing site (Sources: Marine \& Fisheries Agency of Denpasar, 2004).

in the numbers of fishing gear units. Whereas the total catch of sharks using gillnets and other fishing gear types were relatively constant during 1998 to 2002. There was a fluctuation in the production of rays caught by gillnets between $50 \mathrm{t}$ and $600 \mathrm{t}$, 
and between $300 \mathrm{t}$ and $850 \mathrm{t}$ in longlines during the period (Fig. 4b).

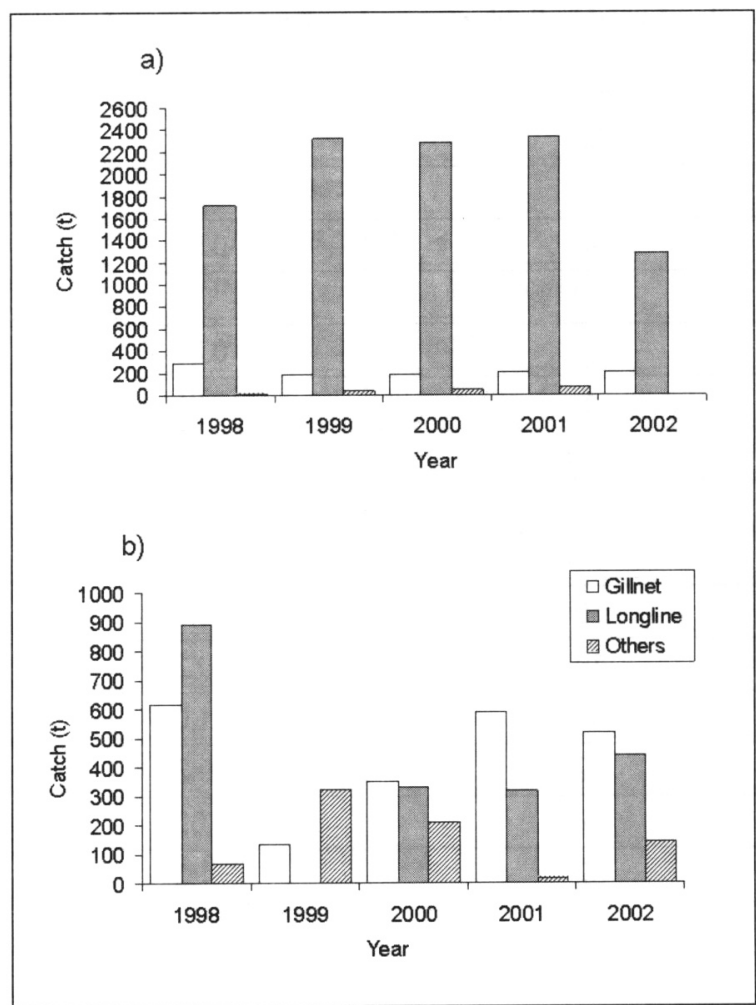

Figure 4. Total catch of sharks (a) and rays (b) based on fishing gear types in West Nusa Tenggara (Sources: Marine \& Fsheries Agency of Lombok, 2003).

\section{Catch and species compositions}

Large pelagic fishes $(84 \%)$ dominated at most catches at Palabuhanratu in 2003, where sharks and rays contributed only $3 \%$ and $1 \%$ from the total catch, respectively (Fig. 5a). At Palabuhanratu port, the fishing activities were dominated by Danish seine nets, tuna gillnets, tuna longlines. Thus, the sharks and rays landed at this site were only as a by-catch from tuna gillnet and tuna longline fisheries.

The catch composition of fish landing at Cilacap in 2003 showed a domination by small ( 35 $\%$ ) and large pelagic fishes (27\%), whereas the catches of sharks and rays were $16 \%$ and $5 \%$ from the total catch, respectively (Fig. 5b). Species composition of sharks from Indian Ocean landed at sites of Cilacap, Pelabuhanratu, KedongananBali and Tanjung Luar-Lombok was shown in Table 2. It seems that Squalus spp. and Carcharhinus falciformis were dominant species in the Indian Ocean which contributed 22.1 a)

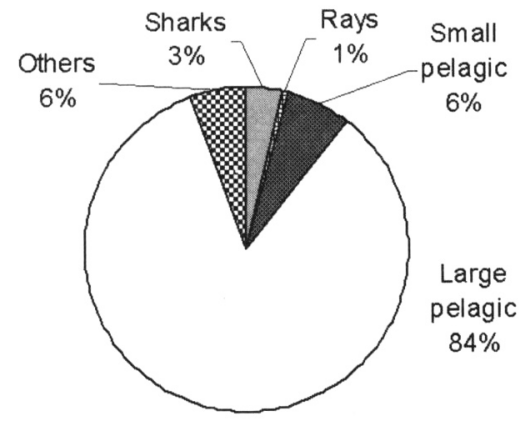

b)

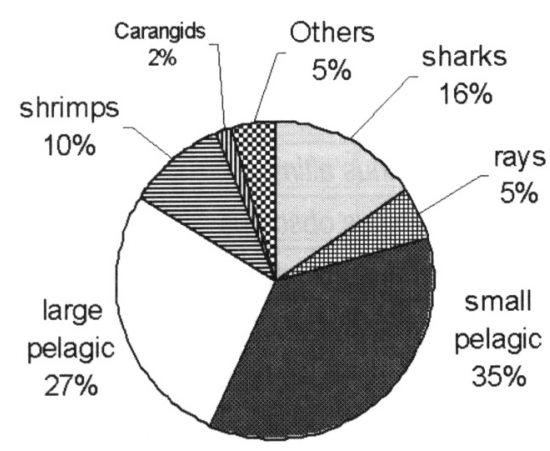

Figure 5. Catch composition at Palabuhanratu (a) and Cilacap landing sites (b) in 2003.

$\%$ and $14.9 \%$, respectively from the total catch of shark.

\section{Abundance species of shark}

During 2001-2004 period, Carcharhinus falciformis was the most abundant species in the shark catches at Tanjung Luar landing site (25\%), followed by Alopias pelagicus, C. obscurus, Sphyrna lewini and Prionace glauca (Fig. 6). According to the seasonal observation from March to November in 2003, the catch pattern of this species was relatively constant (see Fig. 7). In contrast, the catch of $C$. sorrah was relatively fluactuated. The total catch of this species was the highest in April 2003, but then decreased in the following months. In addition, the contribution of $C$. sorrah in the total catch of sharks during 2001-2004 period was quite low. This condition also happened to the Alopias superciliosus catch. This species was the most abundant in the shark catch in September 2003, but in general, it 
Table 2. Species composition of sharks from Indian Ocean landed at Cilacap, Pelabuhanratu, Kedonganan and Tanjung Luar landing sites during 2002-2004.

\begin{tabular}{|c|c|c|c|}
\hline Number & Species & Number of individual & Percentage \\
\hline 1 & Alopias pelagicus & 443 & 7.0 \\
\hline 2 & Alopias superciliosus & 55 & 0.9 \\
\hline 3 & Atelomycterus marmoratus & 7 & 0.1 \\
\hline 4 & Atelomycterus sp.1 & 4 & 0.06 \\
\hline 5 & Chiloscyllium punctatum & 22 & 0.4 \\
\hline 6 & Chiloscyllium indicum & 2 & 0.03 \\
\hline 7 & Chaenogaleus macrostoma & 1 & 0.01 \\
\hline 8 & Centrophorus sp. & 170 & 2.08 \\
\hline 9 & Chiloscyllium sp. & 2 & 0.03 \\
\hline 10 & Carcharhinus albimarginatus & 74 & 1.2 \\
\hline 11 & Carcharhinus melanopterus & 50 & 0.8 \\
\hline 12 & Carcharhinus altimus & 10 & 0.2 \\
\hline 13 & Carcharhinus obscurus & 62 & 1.0 \\
\hline 14 & Carcharhinus plumbeus & 12 & 0.2 \\
\hline 15 & Carcharhinus macloti & 6 & 0.09 \\
\hline 16 & Carcharhinus obscurus & 82 & 1.3 \\
\hline 17 & Carcharhinus amblyrhynchos & 146 & 2.4 \\
\hline 18 & Carcharhinus limbatus & 24 & 0.4 \\
\hline 19 & Carcharhinus amblyrhynchoides & 1 & 0.01 \\
\hline 20 & Carcharhinus brevipinna & 748 & 12.2 \\
\hline 21 & Carcharhinus falciformis & 911 & 14.9 \\
\hline 22 & Carcharhinus limbatus & 125 & 2.0 \\
\hline 23 & Carcharhinus leucas & 8 & 0.1 \\
\hline 24 & Carcharhinus sorrah & 150 & 2.5 \\
\hline 25 & Carcharhinus longimanus & 36 & 0.6 \\
\hline 26 & Carcharhinus macloti & 9 & 0.15 \\
\hline 27 & Cephaloscyllium sp. E & 4 & 0.07 \\
\hline 28 & Cirrhigaleus barbifer & 1 & 0.01 \\
\hline 29 & Galeocerdo cuvier & 42 & 0.69 \\
\hline 30 & Heptranchias perlo & 11 & 0.18 \\
\hline 31 & Hemigaleus microstoma & 46 & 0.75 \\
\hline 32 & Haleolurus boesamani & 36 & 0.59 \\
\hline 33 & Hemitriakis sp. & 190 & 3.11 \\
\hline 34 & Hexanchus griseus & 5 & 0.08 \\
\hline 35 & Hexanchus nakamurai & 5 & 0.08 \\
\hline 36 & Hemigaleus microstoma & 11 & 0.18 \\
\hline 37 & Hydrolagus sp. & 11 & 0.18 \\
\hline 38 & lago garricki & 1 & 0.01 \\
\hline 39 & Isurus paucus & 7 & 0.1 \\
\hline 40 & Isistius brasiliensis & 3 & 0.05 \\
\hline 41 & Isurus oxyrhynchus & 47 & 0.8 \\
\hline 42 & Isistius brasiliensis & 3 & 0.05 \\
\hline
\end{tabular}


Table 2. (continued).

\begin{tabular}{|r|l|c|r|}
\hline Number & Species & Number of individual & Percentage \\
\hline 43 & Loxodon macrorhinus & 52 & 0.77 \\
\hline 44 & Mustelus spp. & 169 & 2.8 \\
\hline 45 & Nebrius ferrugineus & 3 & 0.05 \\
\hline 46 & Orectolobus sp. & 43 & 0.7 \\
\hline 47 & Prionace glauca & 214 & 3.5 \\
\hline 48 & Pseudocarcharias kamoharai & 58 & 0.95 \\
\hline 49 & Pseudotriakis microdon & 1 & 0.01 \\
\hline 50 & Rhizoprionodon oligolinx & 20 & 0.33 \\
\hline 51 & Rhizoprionodon acutus & 127 & 2.1 \\
\hline 52 & Squalus spp. & 1351 & 22.1 \\
\hline 53 & Sphyrna lewini & 413 & 6.8 \\
\hline 54 & Sphyrna mokarran & 3 & 0.05 \\
\hline 55 & Sphyrna zygaena & 14 & 0.2 \\
\hline 56 & Stegostoma fasciatum & 1 & 0.01 \\
\hline 57 & Triaenodon obesus & 58 & 0.9 \\
\hline
\end{tabular}

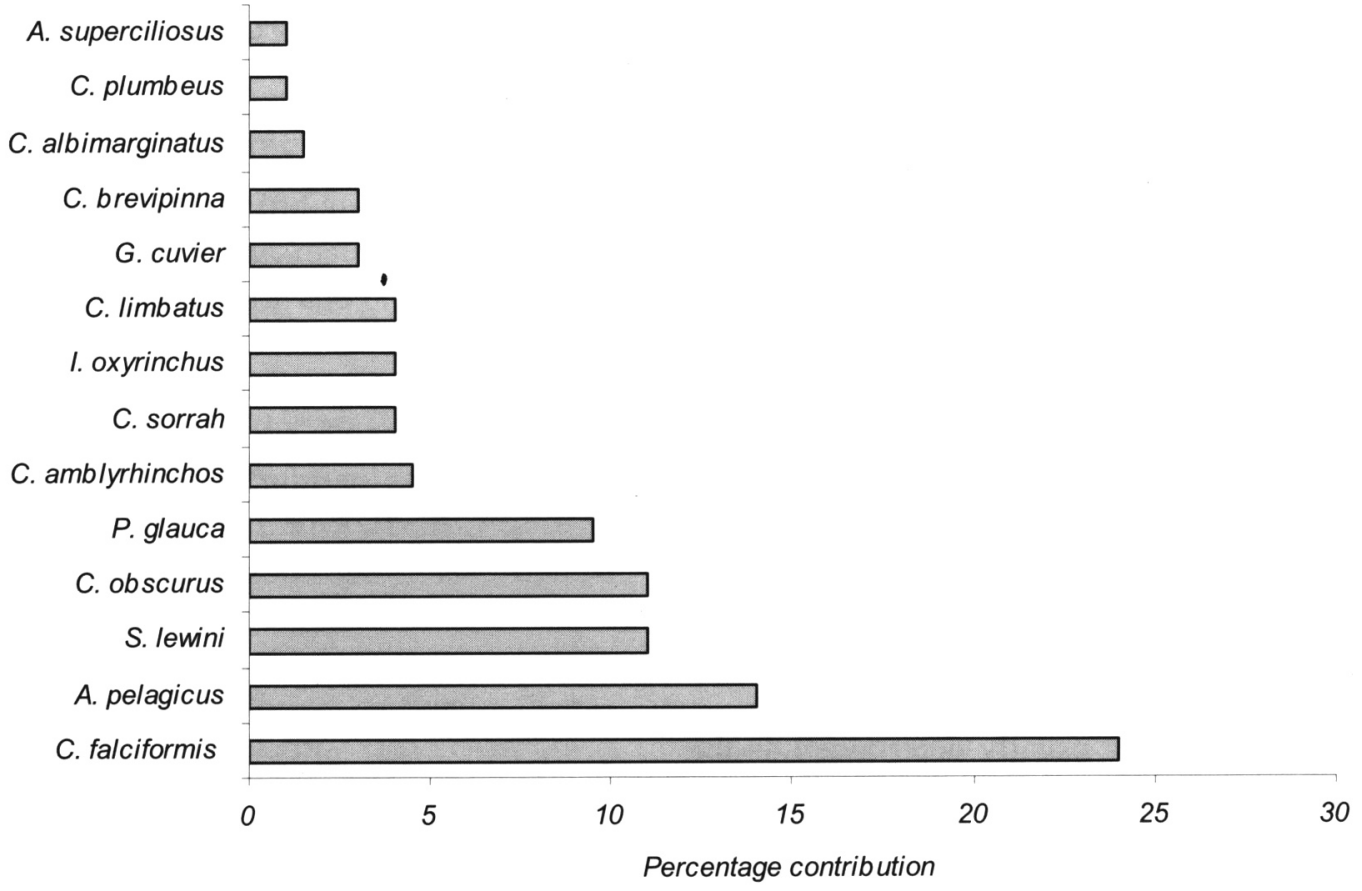

Figure 6. Abundance species of shark catches at Tanjung Luar landing site during observation in 2001-2004.

contributed the least. Generaly, the peak season for shark catches at Tanjung Luar was between March to October, and the off season was possibly between September to February.

\section{Commercial catches of sharks and rays in Indonesia}

The annual catches of sharks and rays in Indonesia over the last 18 years are shown in
Figure 8 . The figure indicates that it has been being a gradual increase in the catches of both sharks and rays over the period, essentially doubling since 1987. In the last three years (since 2001), there was an increase on exported commodity of shark fins from Indonesia to Hongkong. The increase of shark production in Indonesia can give positive and also negative impacts. The positive impacts are the addition of fisher's income and the increasing 


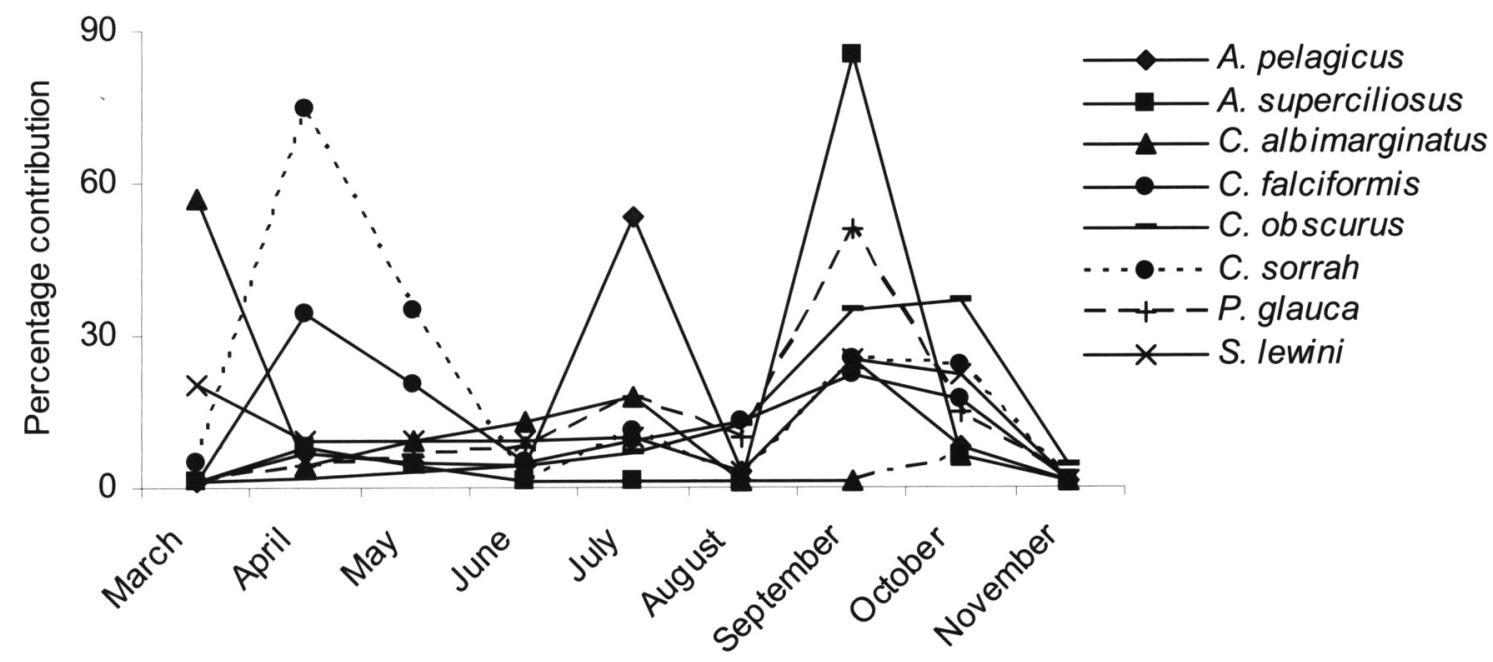

Figure 7. Seasonal observation of shark from March to November in 2003.

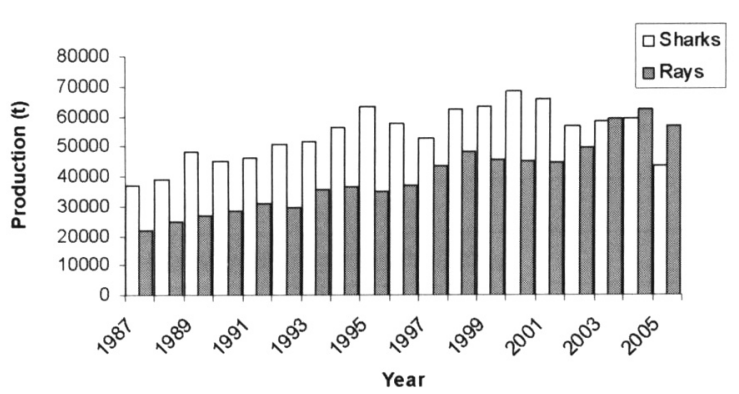

Figure 8. Shark and ray production in Indonesia from 1987 to 2005 (Sources: DGCF, 2006).

of Indonesian devisa. Conversely, it also caused population's stock of sharks and rays in Indonesia being threatened due to the negative impact of shark's exploitation.

\section{Fishing season and fishing area}

Fishing season is usually determined as the time where maximum landing takes place. In general, sharks and rays are landed at Palabuhanratu, Cilacap, Kedonganan and Tanjung Luar landing sites all the year around. For instance, the peak of fishing season occurs in July and October at Cilacap according to landing statistic data for the last two years (Fig. 9).

The fishermen at Palabuhanratu usually go fishing between June and September in the Indian Ocean from the southern part of Java to Sumatra between latitudes $5^{\circ}$ and $9^{\circ} \mathrm{S}$, and longitudes $104^{\circ}$ and $108^{\circ} \mathrm{E}$. Common species landing at this port are deep-water sharks, devil rays Mobula japonica, Prionace glauca, Carcharhinus
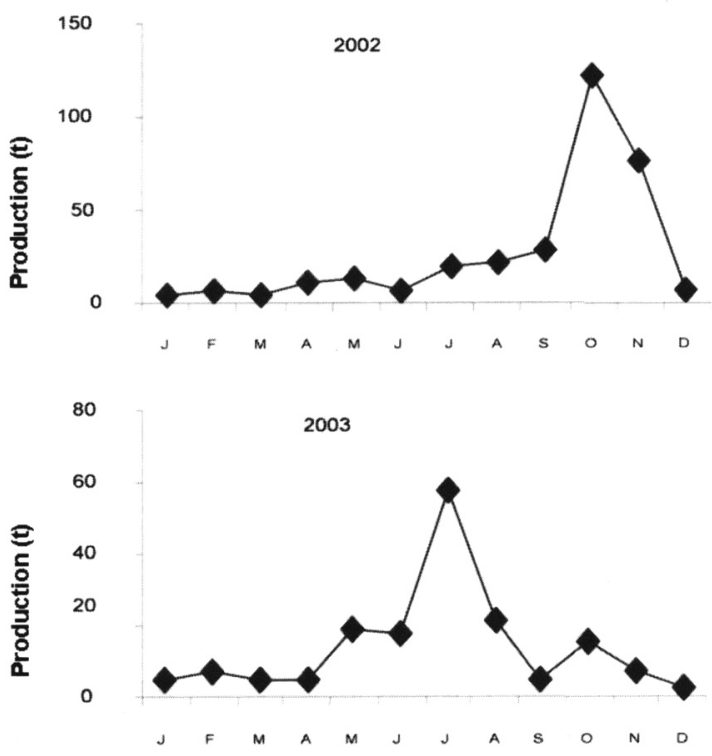

Figure 9. Production of shark at Cilacap in 2002 and 2003.

brevipinna, C. falciformis and Sphyrna lewini. Fishermen from Cilacap usually go fishing between June and September in the Central Java waters between latitudes $8^{\circ}$ and $13^{\circ} \mathrm{S}$ and longitudes $106^{\circ}$ and $111.3^{\circ} \mathrm{E}$. The main fishing area was the waters between 100 and $200 \mathrm{~m}$ in depth. Common species landed at this port are Allopiids and Mobulids. Fishermen who landed their catch at Kedonganan Bali usually go fishing between July and October at around the Jimbaran Bay, while fishermen from Benoa Bali have fishing area from Bali until the Masalembo waters between latitudes $5^{\circ}$ and 11.6 ${ }^{\circ} \mathrm{S}$. Common families that are landed at Kedonganan port were Carcharhinidae, Squalidae, 


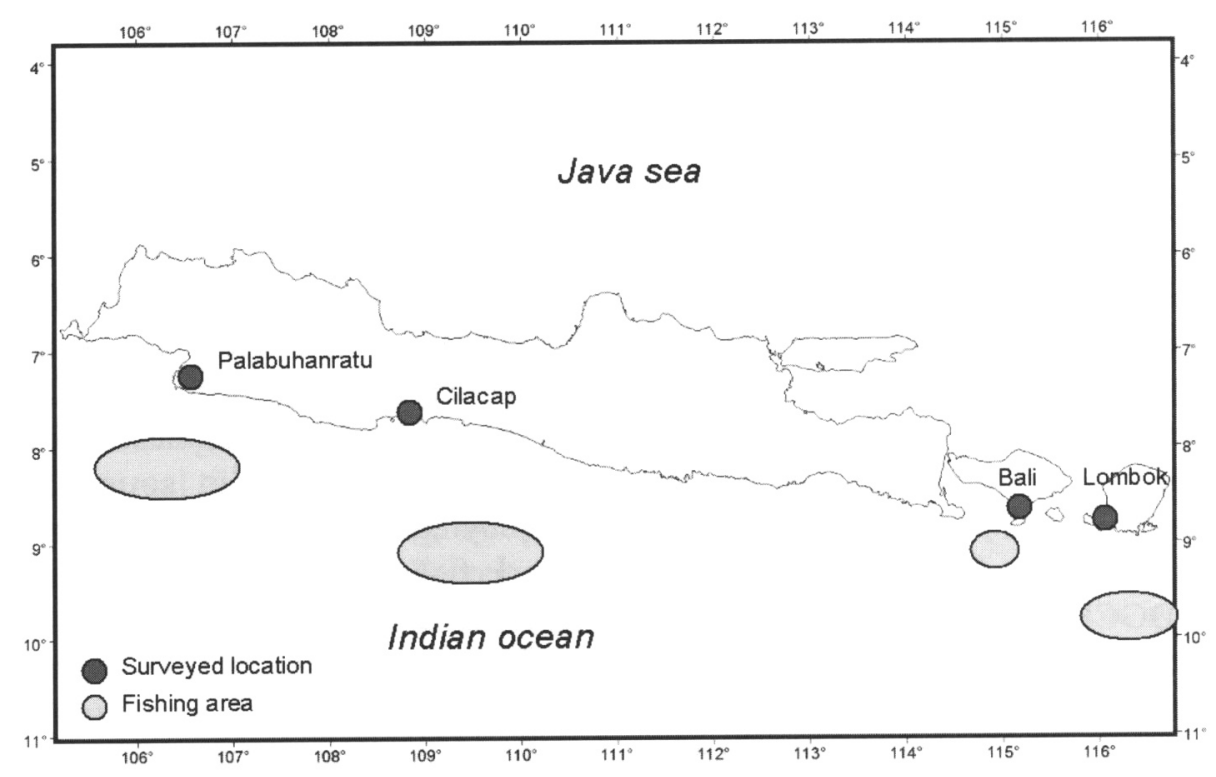

Figure 10. Projected fishing areas of the fishermen from surveyed landing sites.

Rhinobatidae and Dasyatidae. Most of the fishermen landed their catches at Tanjung Luar usually go fishing between June and October, but the fishing activities occur every month. Their fishing area was in the Indian Ocean between Lombok and the northern Australia (latitudes $9^{\circ}$ and $14^{\circ} \mathrm{S}$ and longitudes $116^{\circ}$ and $119^{\circ} \mathrm{E}$ ). Common families landed at this port were Carcharhinidae, Allopidae and Sphyrnidae. The fishing area for the surface longlines are Sumba, Kupang (from May to July) and Sarage, Sembilan and Sabahuna Islands (from August to October). The fishing activities were conducted in about $50 \mathrm{~m}$ depth. In addition, the fishing areas for the bottom longlines were conducted at depth of $30-100 \mathrm{~m}$ around Sumba, east Kupang, Sabu, Ende, Makassar and Rote Island (Fig . 10).

\section{Utilization and marketing of sharks and rays}

At Palabuhanratu, the majority of the elasmobranch catches are processed locally with most of the fleshes being salted and were sent to other markets in Jakarta and West Java. The majority of the catches from Cilacap were processed locally, with most of the fleshes were being salted, dried and were sent to other markets mainly in West Java, while the skins were processed for fashion accessories such as belts, wallets and bags, and they were sent to other markets in Jakarta and Surabaya. Whereas shark fins were sent to Surabaya and Jakarta to be exported. At Kedonganan-Bali and Tanjung Luar, the majority of the catches were processed locally with most of the flesh being salted and dried; fins were dried and the livers were processed to be a shark oil. In Indonesia, it is unusual for the traders to process shark fins before they export them. Normally, traders in Hongkong and Taiwan prefer to import completely dried or frozen fins and process the fins by themselves.

There was a report in Bali that shark cartilage is now increasingly in demand. After fins removal, shark bodies were often filleted and the cartilage was removed. The rest of the body was discarded, because there was not enough space for the carcass in their boats. Taiwanese traders were usually dominated the Bali's fin trades and they also control shark fin prices in Bali. There is a local Taiwan town in Bali, known as Sesetan, where all the Taiwanese fishermen and businesspersons reside. There are three fin dealers who claimed to be able to provide around 4-5 tonnes of dried fins per month. One dealer had about 200-300 kgs of frozen fins and a few tons of dried fins, some of them were being processed on the spot. The fins were from oceanic white tip sharks, threshers, black tips and blue sharks. All fins are usually sent to Surabaya, and then they are exported to other countries.

There are some areas where commonly run the export shark and ray products, such as Jakarta, Surabaya, Bali and Ujung Pandang (Makassar). 
The market chain of shark and ray products are shown in Figure 11 and the prices of various kinds of shark fins are mentioned in Table 3 .

\section{DISCUSSION}

Elasmobranchs are caught in Indonesia by both target fisheries and as by-catch in other fisheries. Target fisheries are mainly artisanal which use a variety of fishing methods, such as gillnets, trammel nets, purse seines, longlines and droplines. Artisanal shark and ray contribute to the national fisheries production in Indonesia. According to DGCF (2006) the shark and ray productions contributed $7.9 \%$ and $6.9 \%$ respectively from the total fish production. Sivasubramaniam (in Steven, 1992) estimated that at least ten thousands tonnes of sharks were caught annually by tuna boats in the Indian Ocean.
This indicated that artisanal fisheries provide an important production for the national fish production. Artisanal fisheries of sharks also have role in fisheries of developing countries such as Argentina (Chiaramonte, 1998), and Brazil (Motta et al., 2005).

The exploitation on chondrichthyans has been recorded in the Mexican artisanal shark fishery in the Gulf of Mexico (Farias and Castillo-Géniz., 1998). As in Indonesia, these artisanal fisheries provide an important source of food and employment in Mexico. However, the Mexican shark fishery is based predominantly on the seasonal abundance of a number of carcharhinid and sphyrnid species that make annual migrations southwards from USA territorial waters (Farias and Castillo-Géniz, 1998), whereas the Indonesian artisanal fisheries are much more diverse and catch large numbers of chondrichthyans throughout the

SHARK \& RAY MARKET CHAIN

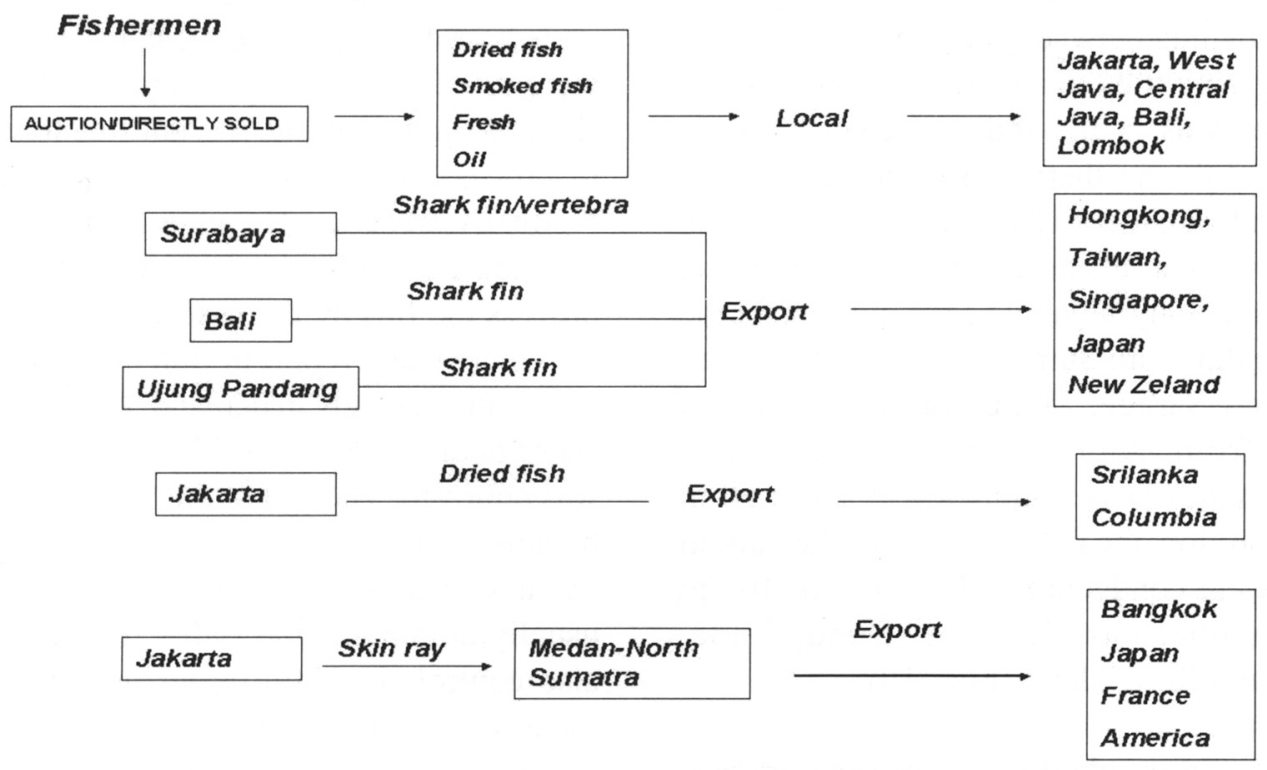

Figure 11. Market chains of shark and ray products in Indonesia.

Table 3. Price list of shark fins in Indonesia.

\begin{tabular}{|l|l|l|}
\hline \multirow{2}{*}{ Size } & \multicolumn{2}{|c|}{ Price in 2004 } \\
\cline { 2 - 3 } & Rhynchobatidae (Rp) & All kinds of shark fins (Rp) \\
\hline $40 \mathrm{~cm}$ & $1.600 .000-2.000 .000$ & 1.250 .000 \\
$33 \mathrm{~cm}$ & $1.200 .000-1.500 .000$ & $1.000 .000-1.100 .000$ \\
$25-30 \mathrm{~cm}$ & $1.000 .000-1.200 .000$ & $850.000-1.000 .000$ \\
$20-25 \mathrm{~cm}$ & $800.000-1.000 .000$ & $650.000-850.000$ \\
$15-20 \mathrm{~cm}$ & $600.000-800.000$ & $450.000-650.000$ \\
$12-15 \mathrm{~cm}$ & $200.000-400.000$ & $200.000-450.000$ \\
\hline
\end{tabular}


year. Thus, any form of future regulation in Indonesia may need to concentrate initially on individual fisheries rather than the chondrichthyan fisheries as a whole. White (2003) mentioned that the greatest concern for the chondrichthyan fisheries in Indonesia is the high level of unreported catches, and the lack of any real management plans. There are three pelagic fisheries operated in the Indian Ocean, i.e. pelagic (shark) longline, tuna longline and tuna gillnet, whereas those for the inshore demersal fisheries, i.e. demersal gillnetting, trawling, trammel netting and fish trapping. It should be recognised, however, that the various fishing methods are used in different habitats. For example, seine netting is undertaken in nearshore, shallow waters, whereas demersal longlining is conducted over the substrate in deep water and tuna longlining is focused at the surface in oceanic waters.

Fishing season of shark and ray artisanal fisheries in Indonesia is related to the weather condition. Rainy season and strong winds can cause the big wave at sea, and this situation can prevent most fishermen to go fishing. This condition usually happens from December to March (west monsoon). In contrast, there are many fishing activities when there is no strong wind and wave on the sea, it generally happens from April to October (east monsoon).

The species composition of the incidental catches has related to some aspects of the fishery, i.e. the role of selectivity and mode of operation. It is also linked to biodiversity and strategies for resources management and marketing (Marin et al., 1998). The most species and commonly recorded families are the Squalidae and Carcharhinidae, which are represented by 1351 and 911 species, respectively, and they contribute of 22.1 and $14.9 \%$ to the total number of individuals of all shark species, respectively. The most abundant carcharhinid species were Carcharhinus falciformis, C. brevippina, Alopias pelagicus and Sphyrna lewini which all together comprised $50.8 \%$ of the total number of sharks caught. According to Dharmadi and Fahmi (2007), C. falciformis was commonly caught by surface longlines at size between 50 and $260 \mathrm{~cm}$ TL in Indian Ocean. In addition, almost $50 \%$ of total catch of $C$. falciformis in western Indonesian waters was of immature size $(<1400$ $\mathrm{mm} \mathrm{TL}$ ) but less than $5 \%$ of them were juveniles (Fahmi and Sumadhiharga, 2007).
The present fish traders in Indonesia could be identified into various types, depending on the quantity, ability, selling methods, products (either fresh or processed), and coverage (local market, inter-city or inter-island). That typology of fish trader may relate to the level of margin rate they got. Kreuzer \& Ahmed (in Tull, 2003) mentioned that shark fins contributed about $5 \%$ in average of the total shark weight, thus it is possible to estimate the tonnage of shark being caught by utilizing the fins exported from Indonesia.

All of the body parts of the elasmobranchs landed are utilised. The flesh, which is often dried, is used for local consumption, whereas the fins, and particularly those of carcharhinid sharks, are dried and exported to other Asian countries where they are highly valued (Chen et al., 1996). Beside carcharhinid sharks, the skins of dasyatid rays are often dried and used by specialist manufacturers to produce wallets, purses, belts and other commodities. Squalene oil from the livers of some shark species (mainly squaloids) is also commonly exported. Indeed, several companies in Indonesia export as much as $48000 \mathrm{~kg}$ of liver oil annually (Chen et al., 1996). Other exported shark products include the dried cartilage of larger individuals and there is a growing demand for specialist products at particular locations, such as the gill rakers of mobulid rays, but there is currently no information on the volume of production or trade of shark cartilage products.

Shark and ray products that are utilised locally include not only dried shark and ray fleshes (as food), but also dried ray tails (used commonly as horse whips) and shark jaws (sales to tourists). The most valuable parts of most sharks are their fins, which are a delicacy in Chinese cuisine. Shark meat is less profitable, which results in a strong economic incentive to cut off the fins and discard the carcass back into the sea, a practice called shark "finning" Shark fins, now among the most expensive seafood products in the world (up to 500 Euro $/ \mathrm{kg}$ ), are exported to east and southeast Asia for processing and preparation of shark fin soup. The European Union (EU) is the world's largest exporter of shark fins to China, the biggest consumer market. Shark meat is usually low valued, but is becoming increasingly popular; reported world landings have tripled since 1985. EU countries (particularly Spain and Italy) were responsible for $56 \%$ of global shark meat imports in 2005. Other shark products on the international 
market include liver oil, skins, cartilage, jaws and teeth (Hareide et al., 2007). Moreover, Lack and Sant (in Hareide et al., 2007) mentioned that Indonesia is a number one of the top twenty shark catching countries in 2003, where $14.09 \%$ of world shark catch. According to FAO data on shark fins, as of 2004 Indonesia is the world's largest producer of shark fins $(1660 \mathrm{t})$ followed by Singapore (1000 t) and India (455 t). From 1998 to 2000, Spain, Indonesia, the United Arab Emirates (UAE), Taiwan and Japan comprised the top five countries importing shark fins to Hong Kong (Hareide et al., 2007).

Family of Carcharhindae (C. falciformis) and Alopiidae (Squalus spp.) were dominant in this study. According to Oshitani et al. (2003), the catch of silky shark (C. falciformis) was the most common shark taken by purse seine fisheries in the eastern Pacific Ocean and it contributed for $25 \%$ of all sharks caught. Another fin dealer uses to export 3-4 tonnes of dried fins directly to Singapore at one time (Watt, 2003). He also mentioned that trade statistics reveal that, during 2000 and 2001, Hongkong imported about 1,400 tonnes of shark fins, (with and without cartilages) from Indonesia. Shark fins have been a high priority to be utilized by those who concerned with shark products. China and other East Asia countries are highly demanding of the shark fins. As the most valuable part of a shark body, fins became the most important part in the shark production in Indonesia. Since early 1980s, exports of dried and salted shark fins have risen significantly from 179 tonnes in 1980 to 894 tonnes in 1996 , with an increase of $39.9 \%$. The major importers of Indonesian shark fins are Hongkong (contributed $46.3 \%$ of the total reported exports of shark fins from Indonesia), Singapore (37.9\%), Malaysia (10.4\%), and Japan $(4.5 \%)$ (Tull, 2003).

\section{CONCLUSION}

The fishing activities of artisanal shark and ray fisheries were found at almost all areas in the south of Indonesia. Large proportions of shark and ray landings were part of products of tuna longlines and tuna gillnets, and also by shark surface and bottom longlines mainly at Tanjung Luar (east of Lombok). The fishing activity occurs every month, but the peak-fishing season of shark and ray usually occurs in July and October. Most of the landings of sharks and rays are processed into dried and salted products for local consumption. While fins, cartilages, and some dried meats and ray skins are exported to some countries in Asia and Europe.

Acknowledgements. We thank to Dr. Stephen Blaber as a project leader from Commonwealth Scientific and Industrial Research Organization (CSIRO) Australia and ACIAR project team who helped collecting the data, especially to Dr. William White (Murdoch University Australia/CSIRO Hobart) and Ms. Jenny Giles. The title of this project is "Artisanal Shark and Ray Fisheries in east Indonesia: their socio-economic and fishery characteristics and relationship to Australian resources".

\section{REFERENCES}

Blaber, S.J.M. 2006. Artisanal shark and ray fisheries in Eastern Indonesia: their socioeconomic and fisheries characteristics and relationship with Australian resources. ACIAR PROJECT FIS/2003/ 037 supplementary stock assessment meeting, CSIRO Cleveland, Australia, 4 September, 2006. $57 \mathrm{pp}$.

Castro, J.I., C.M. Woodley, and R.L. Brudek. 1999. A preliminary evolution of the status of shark species. National Oceanographic and Atmospheric Administration. National Marine Fisheries Service Southeast Fisheries Science Center Miami, Florida, USA, FAO. Fish. Tech. Paper No. 380.

Chen, C.T., K.M. Liu, S.J. Joung, and M.J. Phipps. 1996. Shark fisheries and trade in Taiwan. TRAFFIC East Asia-Taipei, Taipei, Taiwan. 48pp.

Chiramonte, G.E. 1998. The shark genus Carcharhinidae Beaniville, 1816 (Chondrichthyes: Carcharhinidae) in Argentina waters. Mar. Freswater Res., 49: 74752. CSIRO.

Clarke, S.C., M.K. McAllister, E.J. Milner-Gulland, G.P. Kirkwood, C.G.J. Michielsens, D.J. Agnew, E.K. Pikitch, H. Nakano, and M.S. Shivji. 2006. Global estimates of shark catches using trade recordsfrom commercial markets. Ecology Letters, (2006) 9: 1115-1126

Compagno, L.J.V. 1984. FAO species catalogue. Vol. 4. Sharks of the world. An annotated and illustrated catalogue of sharks' species known to date. Part 1. Hexanchiformes to Lamniformes. FAO Fish. Synop. (125) Vol. 4, Pt 1: 249pp

Dharmadi and Fahmi. 2007. Length distribution, total and clasper length relationship and sex ratio of silky shark (C. falciformis). JPPI Vol. 13, No. 3. PRPT-BRKP. (in bahasa Indonesia). 
Directorate General Capture Fisheries (DGCF). 2006 Capture Fisheries Statistics of Indonesia, 2004 Ministry of Marine Affairs and Fisheries. Vol.5, No. 1.

Fahmi and K. Sumadhiharga. 2007. Size, sex and length at maturity of four common sharks caught from Western Indonesia. Mar. Res. Indonesia. Vol. 32, No.1, 2007: 7-19.

Farias, F.M., and J.L. Castillo-Geniz. 1998.Fishery, biology and demography of the Atlantic sharpnose shark Rhizoprionodon terranovae, in the southern Gulf of Mexico. Fish. Res., 39:183-198.

Gloerfelt-Tarp, G.T., and P.J. Kailola. 1984. Trawled Fishes of Southern Indonesia and Nothwestern Australia. ADAB-DFG-GTZ, Singapore, 406pp.

Hareide, N.R., J. Carlson, M. Clarke, S. Clarke, J. Ellis, S. Fordham, S. Fowler, and S. Polti. 2007. European shark fisheries. A preliminary investigation into fisheries, conservation factors, trade products, markets and management measures. European Elasmobranch Association. Brussels. 61pp.

Holt, .D. B, A. Yuliana, O.S. Nishizaki, and N.W. Bartooa. 1998. Pelagic shark fisheries along the west coast of the United States and Baja California, Mexico. Fish. Res., 39 (1998) $115 \pm 125$.

Last, P.R., and J.D. Stevens. 1994. Sharks and Rays of Australia. Fisheries Research and Development Corporation.

Marin, Y.H., F. Brum, L.C. Barea, and J.F. Chocca. 1998. Incidental catch associated with swordfish longline fisheries in the south-west Atlantic Ocean. Mar. Freshwater Res., 49: 633-639.

Motta, S., O.B.F. Gadig, R.C. Namora, F.M.S. Braga. 2005. Size and sex compositions, length-weight relationship, and occurrence of the Brazilian sharpnose shark, Rhizoprionodon lalandii, caught by artisanal fishery from southeastern Brazil. Fish. Res., 74: 116-126.

Oshitani, S., H. Nakano, and S. Tanaka. 2003. Age and growth of the silky shark Carcharhinus falciformis from the Pacific Ocean. Fish. Sci. 69: 456-464.

Stevens. J.D. 1992. Blue and Mako Shark By-catch in the Japanese Longline Fishery off South-eastern Australia Aust. J. Mar. Freshwater Res., 43: 227236.

Sylvana, V.D.M., G. Caille, and R. Gonzales. 1998. Bycatch of sharks in Patagonian coastal trawls fisheries. Mar. Freshwater Res., 49 (7): 641-644.

Tull, M. 2003. Work-in-Progress Report on socioeconomic research on elasmobranch, Indonesia. In: Artisanal Shark and Ray Fisheries in east Indonesia: their socio-economic and fishery characteristics and relationship to Australian resources. June 2003. Second Annual Report FIS 2000/062.

Watt, S. 2003. Shark Fining. Unrecorded wastage on a global scale. Wild Aid. Sanfrancisco. 15pp.

White, T.W. 2003. Aspects of the biology of elasmobranchs in a subtropical embayment in Western Australia and of chondrichthyan fisheries in Indonesia. PhD dissertation, Murdoch University, Perth-Australia. 189pp. 